\title{
The Symbolic and Substantive Representation of LGB Americans in the US House
}

\author{
Eric R. Hansen, University of North Carolina at Chapel Hill \\ Sarah A. Treul, University of North Carolina at Chapel Hill
}

\begin{abstract}
As public opinion in the United States has shifted on questions of gay rights in the last decade, some members of Congress have likewise adjusted their behavior to address issues of concern to their lesbian, gay, and bisexual (LGB) constituents. We argue that the number of LGB constituents in a district affects the representatives' behavior. Although the size of the LGB population positively affects the substantive representation members provide to their LGB constituents, population is conditioned by majority public opinion on LGB issues in determining members' low-cost, symbolic representation of LGB constituents. More favorable majority attitudes toward the minority allow the member to provide more symbolic representation to LGB constituents through low-cost gestures and actions. Statistical tests examining the effects of minority population and public opinion on House members' voting records, bill sponsorships and cosponsorships, and caucus memberships from 2005 to 2011 provide support for our hypotheses.
\end{abstract}

$\mathrm{M}$ inority groups in the United States, particularly racial and sexual minorities, face significant obstacles to extracting favorable policy outcomes from institutions such as Congress, where majorities determine policy outcomes. Groups that have descriptive representation in legislative institutions are able to overcome some barriers; group members provide a voice for the group through floor debate, bill sponsorships, and behind-thescenes interactions between members (Canon 1999; Grose 2011; Haider-Markel 2010). However, minority descriptive representatives alone cannot pass legislation favorable to their group. For this to happen, representatives must win the support of some members of the majority. Thus, majority representatives potentially sympathetic to the minority serve as policy gatekeepers. Understanding the motivations of this subset of lawmakers to support the minority is key to understanding how minority-preferred policy becomes law.

We propose that members of Congress, primarily motivated by reelection (Mayhew 1974), represent minority constituencies on the basis of two related factors: the population of the minority in their districts and the attitudes of the majority of voters in the district toward that minority. With a greater minority population in the constituency, members have greater electoral incentives to provide the group representation through their legislative activities. However, majority public attitudes can condition the relationship between minority population and representation. Members have electoral motivations to be responsive to majority attitudes when providing high-salience, low-cost symbolic representation of minority groups. Because symbolic acts are public and designed to appeal to a wide range of citizens, members use these low-cost activities to convince as many members of their district as possible that they "stand for them" (Pitkin 1967). Thus, for members to engage in symbolic acts supporting the minority, they should also have the support of the majority. However, when it comes to providing low-salience, highcost substantive representation, members are better able to achieve electoral goals by responding to sizable minorities with intensely held views (Bishin 2009). Therefore, the substantive representation of minority groups relies more on the size of the minority in the district and its perceived importance to the member's electoral prospects (Bishin 2009; Canon 1999; Lublin 1997). This distinction will be discussed in greater detail below.

We further develop and test our account by analyzing the relationship between LGB (lesbian, gay, and bisexual)

Eric R. Hansen (ehansen@live.unc.edu) is a PhD student in political science at the University of North Carolina at Chapel Hill, Chapel Hill, NC 27599. Sarah A. Treul (streul@unc.edu) is assistant professor of political science at the University of North Carolina at Chapel Hill, Chapel Hill, NC 27599.

Data and supporting materials necessary to reproduce the numerical results in the paper are available in the JOP Dataverse (https://dataverse.harvard .edu/dataverse/jop). An online appendix with supplementary material is available at http://dx.doi.org/10.1086/682699.

The Journal of Politics, volume 77, number 4. Published online August 11, 2015. http://dx.doi.org/10.1086/682699 
voters and their representatives in the US House of Representatives. ${ }^{1}$ We examine the conditional effects of minority population and majority public opinion on two forms of symbolic representation (position taking and caucus membership) and one form of substantive representation (bill sponsorship). We find that the minority population of a district positively influences the symbolic and substantive representation provided to the group by the district's elected representative. When it comes to symbolic representation, the effect of the LGB population is conditioned upon district majority opinion on gay rights issues. The marginal effect of a LGB population on its symbolic representation is smaller in districts where majority opinion already aligns in favor of gay rights legislation but larger in districts where majority opinion opposes the expansion of gay rights. However, we find that substantive representation does not hinge on public opinion. Rather, it depends upon the electoral power of the minority within a district, as well as the descriptive representation of the minority in Congress. The results imply that minority populations can have a direct effect on their representation in Congress, no matter their size, though that effect may not be strong enough to sway skeptical representatives.

\section{REPRESENTATION OF MINORITY GROUPS}

Majoritarianism is the foundation of democratic theory. The principle of majoritarianism holds that elected officials make decisions that support the preferences of a majority of their constituents. Given that legislators are rational seekers of reelection (Mayhew 1974), the principle of majoritarianism conforms with the notion that legislators act to maximize voter support by taking positions in line with those of the majority of their electorate. However, recent scholarship demonstrates that elected officials occasionally take positions that run counter to majority opinion (Adams, Bishin,

\footnotetext{
1. While lesbians, gay men, and bisexuals are often grouped with trans* people under the broader LGBT label, we limit our analysis only to LGB representation in Congress for several reasons. While Congress has addressed relatively few matters of sexual orientation, it has addressed even fewer matters of gender identity. Legislators frequently consider the subjects as separate policy domains; bills sponsored and brought to a vote often address sexual orientation and neglect gender identity. Unlike LGBs, trans* people have had no descriptive representation in Congress in the legislature's history. Even compared to LGBs, the population of trans people is estimated to be incredibly small; the Human Rights Campaign estimates it between $0.25 \%$ and $1 \%$ of the American population. Although congressional representation of the interests of trans ${ }^{*}$ people is an issue meriting scholarly attention, we consider the populations and interests of LGBs and trans ${ }^{*}$ people to be sufficiently different to merit separate analyses. The trans ${ }^{\star}$ label is used metaphorically to capture all of the identities that fall outside of traditional gender norms.
}

and Dow 2004; Bishin 2009; Lax and Phillips 2012) and that they will represent a minority group's preferences through their official activities (Grose 2011; Lublin 1997). Given majoritarianism, why is it that elected officials occasionally decide to buck popular opinion and favor policies that a minority group supports? Answering this question will help to explain why, despite their historic underrepresentation in American political institutions, minority groups have been able to extract some favored policies from legislatures.

In addition to simply supporting majority-preferred legislation, another way for legislators to maximize voter support in an election is to cobble together support from different subconstituencies until the reelection constituency is sufficiently large enough to return the representatives to office (Bishin 2009; Bishin and Smith 2013). Thus, under the subconstituency theory, minority voters can form a significant portion of a candidate's reelection constituency, allowing legislators to occasionally disregard majority opinion to support the minority (Bishin and Smith 2013). Additionally, the subconstituency theory of representation holds that minority groups that are engaged and active on particular issues are more likely to receive representation on those issues in the legislature (Bishin 2000, 2009; Bishin and Smith 2013). Legislators may respond to the minority constituency in their districts by siding with them on floor votes or sponsoring bills the minority favors, much the same way they may respond to other subsets of their broader constituency (Fenno 1978; Grose 2011). Minority groups are important to legislators given that they are behaving in an environment of electoral uncertainty (Fenno 1978). Given this uncertainty, legislators are interested in winning the support of as many constituents as possible to help secure the vote. Therefore, even minority groups can become an important voting bloc in the eyes of the legislator. If the legislator can demonstrate her support for the group's interests and goals, the legislator can likely secure the minority's vote.

When majority opinion in a congressional district conflicts with the interests of the minority, the representative must focus her activities on representing the interests of the majority or else risk losing majority electoral support. If the two sets of interests do not conflict, or the majority is supportive of or indifferent toward the interests of the minority, then the representative may focus her activities on providing representation to both groups in an attempt to maximize electoral support. Thus, when majority opinion favors the minority, the minority is able to reap the representational benefits regardless of its population size. Furthermore, the legislator's consideration of the majority's opinion will be contingent upon the type of representation the member is providing. 


\section{Symbolic and substantive representation}

Representation can be provided in many forms (Canon 1999; Hall 1996; Pitkin 1967). Pitkin (1967) conceives of representation taking four forms: formalistic, descriptive, symbolic, and substantive. To answer our question of why members represent minority groups, we adopt Pitkin's theoretical framework and focus our attention on symbolic and substantive representation. Each is a form of representation that all members of Congress can provide to minority constituents, regardless of their own social group membership, while in office. ${ }^{2}$ By another account, substantive and symbolic representation both fall into the category of "policy representation," by which members address constituents' policy concerns (Harden 2013).

Symbolic representation constitutes a low hurdle of representation that many members of Congress can easily clear. According to Pitkin (1967), symbolic representation is the way a representative "stands for" the represented. By Pitkin's definition, symbolic representation does not require the representative to act in a way that furthers the interests of the represented. Rather, it only requires the belief of the represented that their agent shares their interests. Consequently, any gesture that symbolizes a commitment to the group or symbolizes an ideal that the group espouses could be taken as symbolic representation. Members of Congress frequently perform such low-cost, symbolic acts to appeal to constituents, like naming post offices after district community leaders, cosponsoring bills important to their constituency, or casting votes on symbolic resolutions. Symbolic acts are, almost by definition, public acts meant to appeal to a wide range of citizens. Members have an incentive to make these acts appeal to as many citizens as possible in order to convince a maximum number of constituents that the member "stands for" them. Symbolic representation is likely to be given to a large number of subconstituencies, given its low cost to the member and given members' electoral incentives to maximize support among various subconstituencies (Bishin 2009). Thus, we expect that symbolic representation can be given to both majority and minority groups in a constituency, provided that a symbolic act meant to appeal to one group does not alienate the other group from the member.

2. Descriptive representation gives social groups a voice in political institutions (e.g., Bratton and Haynie 1999; Haider-Markel 2010; Mansbridge 1999). We take descriptive representation into account in our statistical models below. Formalistic representation describes citizens' authorization of members to represent them in political institutions through elections and is thus irrelevant to our discussion of what members do while in office.
In contrast, substantive representation is the extent to which the representative actively works to advance the policy preferences of the represented (Pitkin 1967). Substantive representation becomes manifest in high-cost, low-salience activities like bill sponsorship. Such activities require a substantial commitment of members' time and resources (Schiller 1995). Different than symbolic representation because of its high-cost nature, substantive representation hinges more upon the involvement of passionate, committed groups lobbying members to take specific actions to support the group. The members most willing to give substantive representation to a group, especially a minority group, likely fall into two categories. First, there are those who have a significant electoral stake in representing the minority because the minority constitutes a large proportion of their constituency (Bishin 2009; Canon 1999; Lublin 1997; Swain 1993). That is, those members who believe the minority group in the district makes up a significant portion of the their reelection constituency (Fenno 1978) are more likely to engage in the higher-cost form of representation (Bishin 2009). Second, there are those who have a personal stake in its representation because they belong to the minority group (HaiderMarkel 2010; Reynolds 2013). Thus, substantive representation of minority groups depends more on the size and commitment of the minority than it does on the attitudes of the majority.

\section{Hypotheses}

We expect that minority population and majority public opinion differently affect the symbolic and substantive representational behaviors that a member engages in. The discussion above leads us to generate two hypotheses:

H1. A larger district minority group population leads to more symbolic representation provided by the member, conditioned upon positive attitudes of the majority toward the minority group.

More favorable majority attitudes toward a minority will allow the member to provide more symbolic representation to the minority through low-cost gestures and actions, ceteris paribus. The member gains a marginal electoral advantage from the minority through such symbolic representation but will not gain that advantage at the cost of majority support.

H2. A larger district minority group population leads to more substantive representation provided by the member, regardless of the attitudes of the majority toward the minority group. 
More favorable majority attitudes alone do not provide incentive to members to devote a great deal of their limited time and resources to providing substantive representation to a minority group. Members must have a sufficient electoral stake, in terms of having a large active minority subconstituency, or a personal stake, as a member of the minority group, as an incentive for them to provide substantive representation.

\section{LGBS as a political minority}

To test these hypotheses, we explore the representation of LGB Americans in the US House of Representatives. The representation of LGBs in the House provides an ideal test case for this theory for three reasons. First, LGBs form a cohesive minority group with a distinct set of group interests. Research shows that LGB identifiers exhibit group cohesion on political matters even without group mobilization on salient issues (Egan 2012) and exhibit largely similar (liberal) political attitudes and voting behavior (Herek et al. 2010; Hertzog 1996; Lewis, Rogers, and Sherrill 2011; Schaffner and Senic 2006). Egan (2012) notes that although sexual orientation is unchangeable, LGBs do not have to choose to identify. Thus, those who choose to identify as LGB tend to exhibit cohesion on LGB issues and can be characterized as having the "intense preferences" that Bishin (2000) argues are necessary for a legislator to acknowledge and pay attention to the subconstituency and its issues. LGBs also have a set of group interests distinct from those of heterosexual voters, who are either already granted certain rights through legal opposite-sex marriage or do not face discrimination on the basis of their sexual orientation. Policies that would objectively benefit LGBs include bans on employment and housing discrimination on the basis of sexual orientation, legalized same-sex marriage, second-parent adoption, and protection under hate crimes laws (Lax and Phillips 2009b; Schaffner and Senic 2006). Second, LGB populations vary across congressional districts. In some urban areas such as San Francisco and Miami, LGBs make up a larger portion of the population compared to other, more rural, districts where very few individuals identify as lesbian, gay, or bisexual. In districts where a sufficient population dwells, LGB voters can form one such constituency that members must appeal to in order to win reelection. With LGB citizens perhaps comprising up to $10 \%$ of the population in some urban areas (Gates and Newport 2013), some members have a great deal to gain from appealing to LGB voters. Third, LGBs have experienced a surge in acceptance by the American public since 2000 (Newport 2011). However, LGB acceptance has increased at different rates in different regions of the country. These differences can in part be explained by localized, personal contact between LGBs and heterosexuals. Among heterosexuals, being personally acquainted with gays and lesbians strongly predicts a more positive feelings toward sexual minorities (Gentry 1987; Herek and Glunt 1993; Lance 1987; Overby and Barth 2002) and greater support for gay rights legislation (Barth, Overby, and Huffmon 2009; Barth and Parry 2009).

A critical question to be raised about this group case selection is how pro-LGB public opinion can be separated from generally liberal public opinion. To be sure, there is a correlation between holding a liberal ideology and support for LGB rights. However, as data collected for this analysis testify, a liberal district ideology does not necessarily translate into strong district support for gay rights legislation. The Pearson's correlation between district ideology, as measured by the 2008 vote share for the Democratic presidential candidate, and support for gay rights legislation, as measured by district-level estimates of public opinion on samesex marriage obtained from multilevel regression and poststratification (MRP), is $r=0.165$ for the period observed (2005-11). The point can be illustrated further with anecdotal evidence. In 2008, California voted on Proposition 8 banning same-sex marriage. In that election, the state's 6th and 20th congressional districts both voted overwhelmingly (at $74.87 \%$ and $74.33 \%$, respectively) to elect liberal Democrats to the House (Lynn Woolsey and Jim Costa, respectively, each given an ADA rating of $80 \%$ that year). However, Woolsey's district voted against the ban on same-sex marriage at a rate of $69.63 \%$, while Costa's district voted against Proposition 8 at a rate of $27.68 \%$. Thus, given the correlational and anecdotal evidence, liberal opinion and opinion specific to gay rights policy are separable concepts. Further analyses of possible selection effects in this group are provided in the online appendix.

\section{LGB representation in the House}

A small body of research has examined the effects of the descriptive representation of LGBs in local governments (Button, Wald, and Rienzo 1999), state legislatures (HaiderMarkel 2010; Haider-Markel, Joslyn, and Kniss 2000), bureaucracies at the local, state, and federal levels of American government (Lewis and Pitts 2009), and in the comparative perspective of national legislatures (Reynolds 2013). Nearly uniformly, these authors find that the increased presence of LGB members in governing bodies positively predicts substantive policy gains for LGB citizens. Only a handful of openly gay and lesbian representatives have served in the US Congress. ${ }^{3}$ In 2012, six openly gay and bisexual repre-

3. By the authors' count, 12 openly gay men, lesbians, and bisexuals have served in the House of Representatives: Gerry Studds (D-MA), Bar- 
sentatives and one lesbian senator were elected, making the 113th Congress the most diverse yet in terms of the sexual orientation of its membership. These seven members continued to hold office in the 114th Congress. The relative dearth of LGB Americans in the US House indicates an excellent context in which to examine why House members, the vast majority heterosexual, offer substantive and symbolic representation to their LGB constituents.

A cursory glance through the Congressional Record on LGB issues suggests that representation of the group through votes and bill sponsorships has occurred infrequently. One reason for this record is that members of Congress are loath to consider such controversial legislation and risk alienating either supporters or opponents of gay rights. As two observers of LGB issues in Congress note, "Gay rights issues move through the corridors and committee rooms of Capitol Hill in piecemeal fashion, largely because many lawmakers prefer that they be kept off the floor of the House or Senate" (Campbell and Davidson 2000, 370). These authors estimate that Congress only considered 10-20 bills per session relating to LGB interests from 1975 to 1995 , the majority of these not reaching floor votes. Although many heterosexual members of Congress have voted with LGB positions on the issues and introduced pro-LGB bills, they have often done so as a minority within their chamber and within their party. Nonetheless, an increase in the number of bill sponsorships in the last decade and several prominent votes on gay rights issues (most famously, the Don't Ask, Don't Tell Repeal Act of 2010) have created a substantial variation in the representation offered to LGB Americans by members of the House.

\section{DATA, METHODS, AND RESULTS}

In the following models, the unit of analysis is the representative by term of Congress. The outcome of interest is the representation that members of Congress provide to their LGB constituents. Members have the opportunity to represent the interests of subgroups within their constituencies through a range of legislative activities, including their voting record, bill sponsorships and cosponsorships, floor speeches, public stances on issues, demographic composition of their staff, caucus memberships, and appearances at events within their district (Canon 1999; Hall 1996). Here we analyze three

ney Frank (D-MA), Steve Gunderson (R-WI), Jim Kolbe (R-AZ), Tammy Baldwin (D-WI), Jared Polis (D-CO), Mark Takano (D-CA), Kyrsten Sinema (D-AZ), David Cicilline (D-RI), Sean Patrick Maloney (D-NY), Mark Pocan (D-WI), and Mike Michaud (D-ME). We do not count the several members who immediately resigned their seats when a sex scandal or other event publicly outed them. forms of representation as dependent variables in separate models: members' position taking, caucus membership, and bill sponsorship. Taken together, these are meant to capture both symbolic and substantive representation. Specifically, we capture symbolic representation by examining position taking and caucus membership. We examine substantive representation by assessing the representative's bill sponsorship activity.

Members' Position Taking on LGB issues form the first dependent variable meant to capture symbolic representation. Data are collected from the Human Rights Campaign (HRC) Congressional Scorecard. Gay rights issues in Congress have been closely tracked by the HRC, a prominent gay rights interest group, since 2001. HRC assigns ratings to members of the House based on their voting records and bill cosponsorships, with a rating of 0 indicating an anti-LGB record and a rating of 100 indicating a pro-LGB record. ${ }^{4} \mathrm{We}$ consider these votes and cosponsorships to constitute symbolic representation because of the low cost of the actions to members in terms of time and attention. Furthermore, the vast majority of the cosponsorships used to calculate these ratings were associated with bills that were never brought to the floor. While some votes included in the rating were close and substantively important (e.g., the repeal of Don't Ask, Don't Tell), most votes were taken on symbolic resolutions, on bills unlikely to advance through the Senate or to the president, or on bills that passed or failed by such large margins that individual votes were rendered expressive acts. On average, the 12 bills voted upon in the ratings were passed or failed with a margin of about 24 votes. Ratings from the 109th to 111th Congresses (2005-11) are used in this analysis. Here, as well as for the subsequent dependent variables, the terms selected for analysis are those in which Census data on LGB populations, opinion estimates, and dependent variable measures are all available. ${ }^{5}$

Members' Caucus Membership forms the second dependent variable capturing symbolic representation. Members interested in symbolically representing their LGB constituents could express this commitment in recent congresses

4. Scorecards rate House members based on their actions on approximately 10 measures per term. Typically, 5-6 of these measures are votes on germane bills or amendments. Another 4-5 measures included in the rating are bill cosponsorships. Including cosponsorships in this measure on relevant bills allows for a broader sample. The authors also measured position taking through ideal point estimation using the Bayesian IRT method reported by Clinton, Jackman, and Rivers (2004). There are few changes in the results using the ideal points measure. Full results using this measure are reported in the appendix.

5. These three congresses also represent years in which a good deal of attention was paid to gay rights issues on the national agenda. Party control and the party of the president also vary over these three terms. 
by joining the House LGBT Equality Caucus. The caucus has had over 100 members in each congress since its founding. Therefore, we operationalize membership as a dichotomous dependent variable, coded 1 for caucus members and 0 for nonmembers during the 111th Congress (the term in which it was founded). Membership data are gathered from the website of former caucus chair Tammy Baldwin (D-WI).

Members' Bill Sponsorships form the third dependent variable, which captures substantive representation. The dependent variable is a count of the number of pro-LGB bills sponsored by each member of the House in one term. Given our interest in substantive representation here, we count only those bills that provide for substantive policy changes. Thus, we exclude symbolic resolutions from the analysis. Data on bill sponsorships are collected in the 109th to 111th Congresses and are gathered from two sources. ${ }^{6}$ First, we included bills coded in the Congressional Bills Project as "Gender and Sexual Orientation Discrimination," with bills addressing only gender discrimination and not LGB issues excluded from the analysis. Second, we conducted a search of congressional bills on the Congress.gov database using the search terms "sexual orientation," "same-sex," "gay," "lesbian," and "LGBT." Bills from this search were included in the data only if the substance of the bill extended legal rights or privileges to LGBs. ${ }^{7}$

The two principal independent variables in each analysis are district LGB population and district opinion on gay rights issues. Similarly to Haider-Markel (2010, chap. 6), we measure LGB Population as the percentage of all partnered households in the district during each session that identify as same-sex households. ${ }^{8}$ Data are gathered from the American Community Survey, which is an ongoing, annual survey conducted by the US Census Bureau. Values of the proportion of the district population identifying as same-sex cou-

6. This search yielded 13 bills from 10 different sponsors in the 109th Congress, 19 bills from 13 sponsors in the 110th Congress, and 62 bills from 25 sponsors in the 111th Congress.

7. The search terms were included in the language of some bills that moved policy away from the outcome preferred by gay rights groups. An example is Tim Huelskamp's (R-KS) "Military Religious Freedom Protection Act" (HR 3828 in the 111th Congress), which protects members of the military from adverse action if they refuse to make accommodations for the sexual orientation of other members (e.g., officiating over a samesex marriage ceremony) due to sincerely held religious beliefs. Such bills were excluded from the data in order for the data and results to be consistent across observations.

8. No question on the US Census or the American Community Survey (ACS) asks directly whether respondents identify as lesbian, gay, or bisexual. Therefore, we use the number of households with unmarried, same-sex partners as a percentage of all respondents reporting living in partnered households, married or unmarried. ples range from $0.21 \%$ in the Mississippi 3rd (including Meridian and Natchez) to $3.28 \%$ in the California 12th (including San Francisco). Because these data measure the number of same-sex couples in the district, rather than the number of LGB-identifying individuals, they differ in value from the Williams Institute/Gallup estimates of state LGB populations cited above (Gates and Newport 2013).

We examine the impact of both district LGB population and broader district opinion on gay rights issues on symbolic and substantive representation. As a measure of majority attitudes toward the LGB minority, we use public opinion on the issue of same-sex marriage. Direct measures of issue-specific public opinion at the district level are difficult to come by. However, scholars have developed multilevel regression and poststratification (MRP) as a strategy to estimate public opinion in states, congressional districts, and smaller subnational political units (Gelman and Little 1997; Lax and Phillips 2009a; Park, Gelman, and Bafumi 2004; Warshaw and Rodden 2012). Using data from Warshaw and Rodden (2012), we estimate public opinion on same-sex marriage in each district for the period 2004-10. Rather than aggregating estimates across several years, we create term-specific estimates to account for the growing acceptance of same-sex marriage over the time period. Thus, District Opinion is a continuous variable ranging from 0 to 100 , with higher values representing greater district support for same-sex marriage. ${ }^{9}$

Competing pressures apart from district composition affect a member's decision to provide substantive representation to LGB constituents. Prominent among these is the party of the member. Because the two major party platforms maintain opposing stances on LGB issues, members will feel pressure to toe the party line in their actions related to LGB issues, regardless of their own or their constituents' opinions. Thus we include the dichotomous variable Democrat to

9. According to Warshaw and Rodden (2012), these MRP estimates are generated using a combination of individual-, district-, and state-level predictor variables. The individual-level variables are race, gender, and education. The district-level variables are median income, percent veteran population, percent urban population, and percent population dwelling in same-sex households. The state-level variables are percent evangelical population, percent union population, and region. We do not independently test the accuracy of these data. Warshaw and Rodden (2012, 20816) provide evidence that MRP estimates using these data outperform disaggregation, ballot measure returns, and presidential vote share. They also write that calculating estimates using more individual-level variables (e.g., party identification) leads to very modest improvements over estimates with district- and state-level variables only. In other words, the inclusion of more individual-level variables may reduce bias, but the payoff is marginal. Their finding lessens our concerns that omitted variable bias at the individual level fundamentally alters the measure or our results. 
control for party, coded 1 for Democratic House members and 0 for Republicans.

We also control for factors determined to be relevant to members' behavior on LGB issues under morality politics and interest group frameworks (Haider-Markel and Meier 1996, 2003). Under a morality politics framework, representatives are motivated to defer to constituent opinion on highly salient morality issues. Members may not know the exact percentages of their constituents who support or oppose specific policies, and thus they use heuristic devices to estimate district opinion (Fenno 1978; Miler 2009). One such characteristic is District Partisanship, measured as the Democratic vote share in the 2008 presidential election. Democrats have been much more likely to support LGB rights than Republicans. Moreover, with a higher Democratic vote share, members may feel more confident in taking public positions on controversial issues such as gay rights, since it is less likely they will lose enough electoral support from that position to jeopardize their chances of reelection.

We further control for factors that affect members' behavior under an interest group framework. On nonsalient issues, members work with interest groups out of the media spotlight to draft legislation that matches the preferences of the group and the member (Haider-Markel 1999). Thus we include in our model Campaign Contributions, measured as the log of the amount in dollars that the HRC donated to members' campaigns in the election preceding their term in office. The variable is lagged to isolate the effects of such contributions temporally and remove possible endogeneity between campaign contributions and substantive representation provided. Data are gathered from the Center for Responsive Politics.

Finally, members who are descriptive representatives of a group may be more likely to offer substantive representation of that group than the general population (HaiderMarkel 2010; Lublin 1997). Hence, we include LGB Member, a dichotomous variable indicating whether or not the member openly identifies as lesbian, gay, or bisexual (1) or not $(0)$.

\section{The effect of population and opinion on position taking}

The analysis presented examines three dependent variables: an interest group rating between 0 and 100 measuring members' position taking, a dummy variable measuring caucus membership, and a count measuring the number of pro-LGB bills sponsored. Because each dependent variable requires a different estimation technique, we present each in a separate table.
Table 1 displays the results for ordinary least squares (OLS) regression estimates of the effects of the independent variables on members' position taking. We obtained interest group ratings for 1,299 members by term. ${ }^{10}$ Because we use time-series cross-sectional (TSCS) data, we include a lagged dependent variable (Scorecard Rating St-1 ). We report robust clustered standard errors to address problems of autocorrelation and heteroskedasticity. Because our theory predicts differences between districts will affect symbolic representation, rather than differences within districts over time, we include random effects for term and district. We present three restricted models and one fully specified model, but we limit our interpretation of the results to the fully specified model (model 4).

To test hypothesis 1 , that minority population leads to greater symbolic representation conditioned on majority support for the minority, we include a multiplicative interaction term between LGB population and district opinion. The model yields results in line with our expectations. The negative, statistically significant coefficient on the interaction term suggests a conditional relationship between the variables. A marginal effects plot demonstrating this relationship is presented in figure 1. According to the marginal effects estimate, the marginal effect of the mean LGB population on a Democratic member's HRC rating when district support of same-sex marriage is at $30 \%$ is about 15.9 points on average, when all other variables are held at their means. This is an impressive marginal effect, given that the range of the dependent variable is 0 to 100 . When district support increases to $70 \%$, the marginal effect of LGB population decreases to 1.7 points on average. As the broader public increases its support for same-sex marriage, the magnitude of the effect of LGB population on symbolic representation decreases. Thus, we find support for hypothesis 1 .

Partisan differences also play a major role in position taking on LGB issues, however. Controlling for the other factors in the model, Democrats on average score more than 30 points higher than Republicans on the HRC rating scorecard. The pro-LGB interest group campaign contributions also have statistically significant, positive effects on representatives' position taking. Surprisingly, as a district votes more strongly Democratic, its representative is not more likely to vote in favor of gay rights legislation, controlling for the

10. The sample size also changes across the models because our simulation of district opinion estimates failed to converge for five observations. The use of multiple imputation to account for the missing cases did not change the coefficient estimates. We report all models in this article without using multiple imputation in order to provide postestimation model fit statistics. 
Table 1. OLS Regression Results for Position Taking on LGB Issues, 109th to 111th Congresses

\begin{tabular}{|c|c|c|c|c|}
\hline & \multicolumn{4}{|c|}{ Dependent Variable: HRC Scorecard Rating } \\
\hline & (Model 1) & (Model 2) & (Model 3) & (Model 4) \\
\hline \multirow[t]{2}{*}{ LGB population } & $5.015^{\star}$ & & $4.591^{\star}$ & $26.585^{\star}$ \\
\hline & $(1.749)$ & & $(1.806)$ & $(7.099)$ \\
\hline \multirow[t]{2}{*}{ District opinion } & & $.104^{\star}$ & .080 & $.304^{*}$ \\
\hline & & $(.052)$ & $(.053)$ & $(.091)$ \\
\hline \multirow[t]{2}{*}{ LGB population $\times$ district opinion } & & & & $-.356^{\star}$ \\
\hline & & & & $(.104)$ \\
\hline \multirow[t]{2}{*}{ Campaign contributions } & $6.224^{*}$ & $6.256^{*}$ & $6.157^{\star}$ & $6.109^{*}$ \\
\hline & $(.765)$ & $(.776)$ & $(.770)$ & $(.764)$ \\
\hline \multirow[t]{2}{*}{ Democrat } & $29.982^{*}$ & $29.856^{*}$ & $30.362^{\star}$ & $30.597^{*}$ \\
\hline & $(2.516)$ & $(2.493)$ & $(2.518)$ & $(2.500)$ \\
\hline \multirow[t]{2}{*}{ District partisanship } & .038 & .037 & .036 & .036 \\
\hline & $(.032)$ & $(.033)$ & $(.033)$ & $(.032)$ \\
\hline \multirow[t]{2}{*}{ LGB member } & 2.636 & 2.792 & 2.782 & 2.594 \\
\hline & $(4.770)$ & $(4.982)$ & $(5.038)$ & $(4.937)$ \\
\hline \multirow[t]{2}{*}{ Scorecard rating $_{t-1}$} & $.412^{*}$ & $.418^{\star}$ & $.408^{*}$ & $.406^{*}$ \\
\hline & $(.038)$ & $(.038)$ & $(.038)$ & $(.038)$ \\
\hline Term random effects & Yes & Yes & Yes & Yes \\
\hline District random effects & Yes & Yes & Yes & Yes \\
\hline \multirow[t]{2}{*}{ Constant } & -1.042 & -3.717 & -5.009 & $-18.580^{\star}$ \\
\hline & $(1.647)$ & $(4.982)$ & $(3.040)$ & $(5.570)$ \\
\hline Observations & 1,299 & 1,294 & 1,294 & 1,294 \\
\hline$R^{2}$ & .893 & .893 & .893 & .894 \\
\hline
\end{tabular}

Note. Robust clustered standard errors are in parentheses. ${ }^{*} p \leq .05$.

other variables in the model. Finally, the effect of being a LGB member of the House does not significantly predict a higher rating on gay rights issues. Although the sign of the coefficient is in the expected direction, we suspect that the lack of statistical significance in this result is due to the small number of openly LGB representatives serving over this time period.

\section{The effect of population and opinion on caucus membership}

Next we examine the factors affecting members' decisions whether to join the House LGBT Equality Caucus as another measure of symbolic representation and another test of hypothesis 1 . On the whole, the results presented in table 2 closely reflect the results of the previous OLS regression examining members' position taking. Because caucus membership here is treated as a dichotomous dependent variable, estimates are obtained using logistic regression. The sample for models 5-8 includes the 435 members in the 111th Congress, the only term in our data set after the caucus' formation in 2008. Because the data for this model are cross-sectional, the time-series adjustments included in the models in table 1 are not included here. The dichotomous variable indicating LGB members of the House is excluded from these models because all LGB-identifying members of the House serve as cochairs of the caucus.

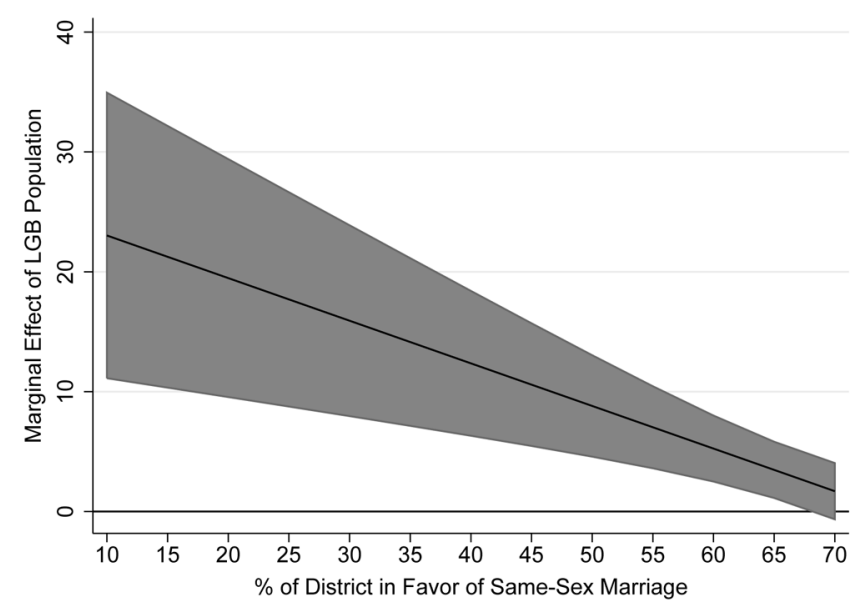

Figure 1. Marginal effect of LGB population on position taking given district opinion. 
Table 2. Logistic Regression Results for Caucus Membership, 111th Congress

\begin{tabular}{|c|c|c|c|c|}
\hline & \multicolumn{4}{|c|}{ Dependent Variable: House LGBT Equality Caucus Membership } \\
\hline & (Model 5) & (Model 6) & (Model 7) & (Model 8) \\
\hline \multirow[t]{2}{*}{ LGB population } & $2.533^{*}$ & & $2.475^{\star}$ & $16.204^{\star}$ \\
\hline & $(.660)$ & & $(.659)$ & $(3.899)$ \\
\hline \multirow[t]{2}{*}{ District opinion } & & $.038^{*}$ & $.035^{*}$ & $.186^{*}$ \\
\hline & & $(.016)$ & $(.016)$ & $(.044)$ \\
\hline \multirow[t]{2}{*}{ LGB population $\times$ district opinion } & & & & $-.225^{\star}$ \\
\hline & & & & $(.059)$ \\
\hline \multirow[t]{2}{*}{ Campaign contributions } & $.511^{\star}$ & $.584^{*}$ & $.445^{\star}$ & $.385^{\star}$ \\
\hline & $(.151)$ & $(.150)$ & $(.153)$ & $(.157)$ \\
\hline \multirow[t]{2}{*}{ Democrat } & 2.195 & 1.858 & $2.380^{*}$ & $2.413^{\star}$ \\
\hline & $(1.163)$ & $(1.141)$ & (1.173) & $(1.171)$ \\
\hline \multirow[t]{2}{*}{ District partisanship } & $.028^{\star}$ & $.031^{\star}$ & $.025^{\star}$ & $.027^{\star}$ \\
\hline & $(.010)$ & $(.010)$ & $(.010)$ & $(.011)$ \\
\hline \multirow[t]{2}{*}{ Constant } & $-8.070^{\star}$ & $-4.818^{\star}$ & $-6.258^{\star}$ & $-18.890^{\star}$ \\
\hline & $(1.217)$ & $(1.349)$ & $(1.460)$ & $(3.075)$ \\
\hline Log likelihood & -139.825 & -146.440 & -137.487 & -130.548 \\
\hline $\mathrm{BIC}$ & 310.027 & 323.2574 & 311.426 & 303.624 \\
\hline
\end{tabular}

Note. Number of observations $=435$. BIC $=$ Bayesian information criterion. Standard errors are in parentheses. ${ }^{*} p \leq .05$.

Again, we limit our interpretation of these results to the fully specified model (model 8). When population and district opinion are interacted, we find a statistically significant, negative coefficient estimate for the interaction term, just as in model 4 of table 1 . The predicted probability of a Democratic member joining the caucus across a range of district opinion and LGB population values, with all other variables held at their means, is presented in figure 2 .

Here, as in figure 1, the effects of population and district opinion move jointly and inversely. As district support for same-sex marriage increases, the marginal effect of district LGB population on a member's probability of joining the caucus decreases. This is illustrated by the plot showing the marginal effects of an increase in a district LGB population at three arbitrarily chosen levels of public support. When support is already high (65\%), the LGB population does little to affect a member's probability of joining the caucus. The line representing high support demonstrates a much more gradual increase in the likelihood of caucus membership as LGB population increases than the other lines representing medium (50\%) and low (35\%) support. In these latter two cases, low district support and a small LGB population translate to a low likelihood of caucus membership. However, the marginal effect of the district LGB population is large; an increase in the LGB population above the variable mean $(0.64 \%)$ translates into a large increase in the likeli- hood of a member joining the caucus. Thus, the size of the district LGB population is less persuasive to members joining the caucus in districts where support is high than it is to members in districts where support is lower.

We continue to see here that greater LGB populations receive greater symbolic representation when majority support for same-sex marriage is high. Thus, hypothesis 1 also receives support from this set of models. Finally, as in table 1, the control variables measuring campaign contributions and (in two of the four models) Democratic party affiliation exert

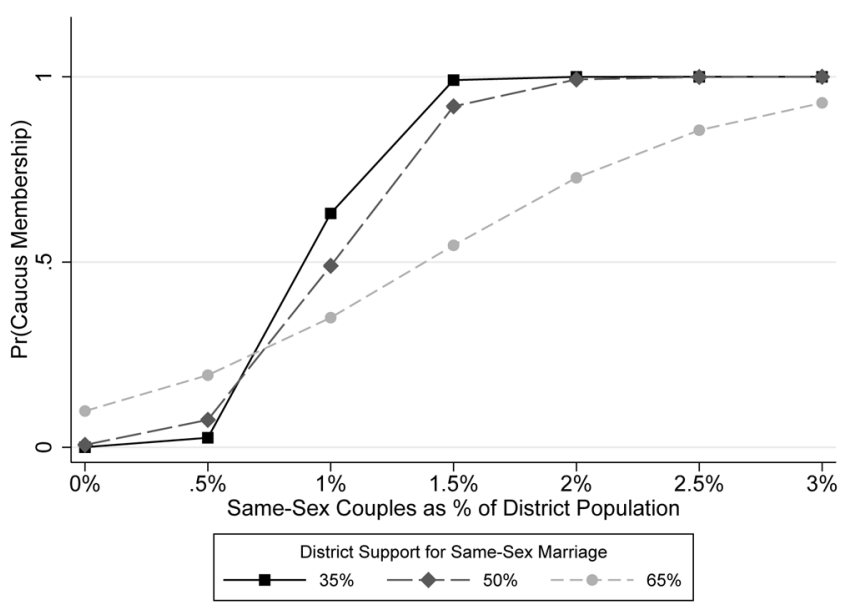

Figure 2. Probability of caucus membership given LGB population and district opinion. 
statistically significant, positive effects on caucus membership. In line with expectations, but differently than in table 1, the results here indicate that as the Democratic vote share in a district increases, so too does the member's likelihood of joining the LGBT Equality Caucus, controlling for the other variables.

\section{The effect of population and opinion on bill sponsorship}

Whereas the last two sets of models examined the factors explaining why members offer minority groups symbolic representation, our final set of models examine why they offer substantive representation. We expect a different set of factors to be at play in substantive representation than in symbolic representation. Table 3 shows the effects of LGB population and district opinion on the number of pro-LGB bills sponsored by each member. Because the dependent variable in these models is a count and the conditional variance of the dependent variable is overdispersed relative to the conditional mean, the models are estimated using negative binomial regression. ${ }^{11}$ The sample for these models include all members of the 109th to 111th Congresses.

Here we look for support for hypothesis 2, that a larger minority group population leads to greater substantive representation regardless of majority attitudes. When district opinion and LGB population are considered side by side in model 11, the estimate of the effect of district opinion fails to achieve significance at the .05 level of confidence, but higher LGB population positively predicts a higher count of bill sponsorships. As in previous models, we consider a conditional relationship between the two variables in model 12. The coefficient estimate for the interaction term between opinion and population fails to achieve statistical significance at the .05 level of confidence, though this fact in and of itself does not rule out a conditional relationship. In results not reported here, we find the marginal effect of LGB population given district opinion is never statistically significantly different from zero across the range of values of district opinion. Given the insignificant findings from measures of public opinion and based on model fit, as measured by BIC, we report the results in model 9 (incorporating LGB population and not district opinion) as the correctly specified model.

11. We attempted to use the same estimation techniques for timeseries cross-sectional data for these models as in the position taking models above. However, there were insufficient data for the model to be calculated. As a result, we estimate this negative binomial model using a lagged dependent variable, fixed effects for terms, and robust clustered standard errors, but no unit effects for districts. A full explanation of the modeling choice is presented in the appendix.
Turning to the control variables, the only variables that consistently have a significant impact on substantive representation across the models are LGB Member and Sponsorship $_{t-1}$. Taken as a whole, these models suggest that the only three factors significantly and consistently affecting the substantive representation of LGB constituents are (i) the size of the group in the district, (ii) the descriptive representation of the group in elected office, and (iii) past representation of the group. Overall, we find support for hypothesis 2, that an increase in the size of the minority group positively affects the substantive representation the group receives regardless of majority attitudes.

We present expected counts of bill sponsorships based on estimates from model 9 in figure 3. The predicted count displays differences between LGB and non-LGB members by their districts' LGB populations. The predictions are based upon the number of bills likely to be sponsored by Democratic members of the House with all other variables held at their means. The figure shows that, while district LGB population influences members' bill sponsorship activity, descriptive representation has a substantially larger effect. Heterosexual members of Congress are predicted to sponsor one gay rights bill only when they have a very large LGB population in their district ( $3 \%$ of the populaton), controlling for other variables. LGB members, on the other hand, are predicted to sponsor one gay rights bill when $1.5 \%$ of their constituents are same-sex couples.

\section{DISCUSSION}

In majoritarian political institutions, minority groups must work especially hard to achieve representation in the institution. However, the size of minority groups interacts with majority opinion in ways that affect the type of representation that the minority receives. The population of the minority group in a constituency influences the level of symbolic and substantive representation minority groups receive. Representatives pay attention to minority subconstituencies in their districts, even if the population of the group is small. Across the empirical models, we find that the LGB population of a district exerts a statistically significant, positive influence on the representation provided by its member in the House, even controlling for other relevant factors such as member partisanship and district partisanship. The finding that the LGB population matters to representation is particularly impressive given the fact that, across all districts measured, the percentage of same-sex couples among all partnered couples in the data set never exceeds $3.28 \%$. Representatives are aware of even small groups in their districts and, if possible, work to represent their interests in Congress. 
Table 3. Negative Binomial Regression Results for Pro-LGB Bill Sponsorships, 109th to 111th Congresses

\begin{tabular}{|c|c|c|c|c|}
\hline & \multicolumn{4}{|c|}{ Dependent Variable: Number of Sponsorships } \\
\hline & (Model 9) & (Model 10) & (Model 11) & (Model 12) \\
\hline \multirow[t]{2}{*}{ LGB population } & $1.362^{*}$ & & $1.168^{*}$ & .853 \\
\hline & $(.552)$ & & $(.559)$ & $(4.015)$ \\
\hline \multirow[t]{2}{*}{ District opinion } & & $.047^{\star}$ & .035 & .031 \\
\hline & & $(.020)$ & $(.019)$ & $(.047)$ \\
\hline \multirow[t]{2}{*}{ LGB population $\times$ district opinion } & & & & .005 \\
\hline & & & & $(.064)$ \\
\hline \multirow[t]{2}{*}{ Campaign contributions } & .273 & $.316^{*}$ & .255 & .257 \\
\hline & $(.146)$ & $(.132)$ & $(.138)$ & $(.141)$ \\
\hline \multirow[t]{2}{*}{ Democrat } & .606 & .562 & .707 & .702 \\
\hline & $(.793)$ & $(.795)$ & $(.780)$ & $(.773)$ \\
\hline \multirow[t]{2}{*}{ District partisanship } & .018 & .017 & .014 & .014 \\
\hline & $(.011)$ & $(.016)$ & $(.011)$ & $(.011)$ \\
\hline \multirow[t]{2}{*}{ LGB member } & $2.450^{*}$ & $2.605^{\star}$ & $2.533^{*}$ & $2.539^{\star}$ \\
\hline & $(.306)$ & $(.465)$ & $(.388)$ & $(.399)$ \\
\hline \multirow[t]{2}{*}{ Sponsorships $_{t-1}$} & $1.239^{*}$ & $1.190^{*}$ & $1.134^{*}$ & $1.134^{*}$ \\
\hline & $(.473)$ & $(.402)$ & $(.452)$ & $(.452)$ \\
\hline Term fixed Effects & Yes & Yes & Yes & Yes \\
\hline \multirow[t]{2}{*}{ Constant } & $-7.046^{\star}$ & $-8.812^{\star}$ & $-8.786^{\star}$ & $-8.569^{\star}$ \\
\hline & $(1.014)$ & $(1.445)$ & $(1.375)$ & $(3.035)$ \\
\hline Observations & 1,305 & 1,300 & 1,300 & 1,300 \\
\hline Log likelihood & -224.297 & -225.282 & -222.693 & -222.689 \\
\hline $\mathrm{BIC}$ & 520.333 & 522.266 & 524.257 & 531.420 \\
\hline
\end{tabular}

Note. Robust clustered standard errors are in parentheses. BIC $=$ Bayesian information criterion.

${ }^{*} p \leq .05$.

However, while the effect of minority population on substantive representation is direct, its effect on symbolic representation is conditioned by majority opinion. We find that

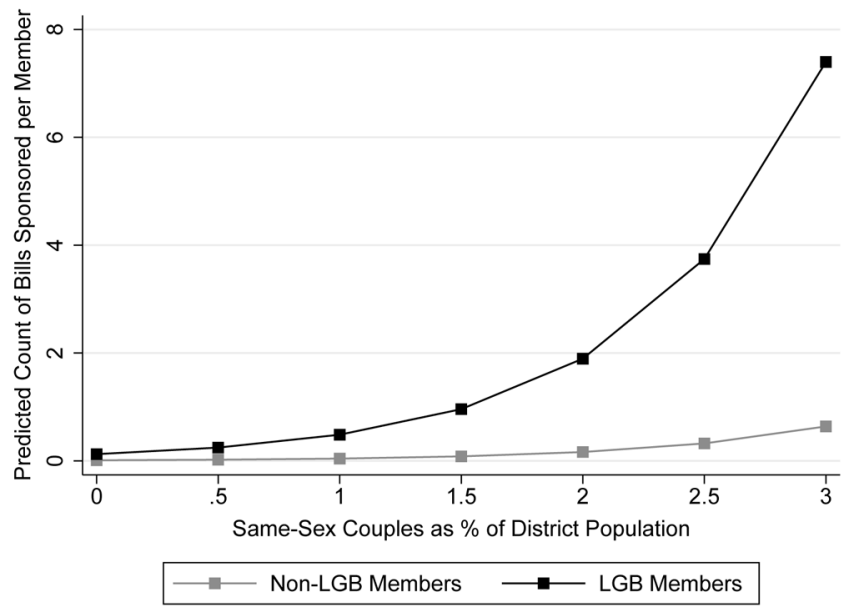

Figure 3. Predicted count of pro-LGB bill sponsorships given LGB population. as the minority population grows, members have a greater electoral incentive to provide substantive representation to that minority, particularly when the group is vocal and shares intense preferences on certain policy issues (Bishin 2009). Members are willing to do the hard, behind-the-scenes work in legislative bodies if they can gain the support of the minority, regardless of majority opinion. However, the extent to which minority populations can influence their representatives to offer symbolic representation (cynically put, "lip service") is heavily dependent on majority attitudes. On one hand, when public opinion toward the minority is unfavorable, minority populations can have a large effect in convincing their representative to provide them with greater symbolic representation. On the other hand, when public opinion is already favorable to the minority, the presence of the minority in the district adds no additional pressure on representatives to offer symbolic representation.

Relatedly, our results show that different sets of actors influence different forms of symbolic and substantive representation. For symbolic forms of representation, such as 
casting a floor vote or cosponsoring a bill, factors such as campaign contributions and party affiliation play a role in determining members' behavior. However, for substantive representation, members respond largely to minority influence, as measured by minority population in the district and minority descriptive representation in the body itself. We draw the conclusion that while broad support from the majority can help the minority achieve broad societal support and eventual policy change, minority incorporation into political institutions is essential for making sure that issues important to the minority find a place on the agenda.

We should note that the models presented here may suffer from problems of endogeneity that are inherent in all research on representation. It may be that constituent voices and demands cause their representatives to be responsive to their concerns, but it also could be that members anticipate constituent demands and act responsively to head off the threat of losing reelection. Alternatively, and fitting with past work on public opinion and representation, members of Congress may find themselves using their own judgment more frequently as broader attitudes toward the LGB population continue to shift, even if their judgment contradicts district opinion (Herrera, Herrera, and Smith 1992; Pitkin 1967).

The present work posits and tests hypotheses from a broad theory of minority representation applicable to various groups. We find evidence that a minority group population, even when small, matters to the group's symbolic and substantive representation provided by elected officials. However, the effect is conditioned by the attitudes of the broader public toward the minority groups. Although this article tests the theory on only one group, LGB Americans, future research may apply the theory in the context of other minority groups.

The findings presented here have mixed normative implications for representative democracy. The results show that the political influence minority groups exert is affected by the opinion of the majority population toward the group. Representatives are responsive to majority district opinion, perhaps at the cost of minority representation. Essentially, this research confirms that Madison was correct to be concerned for the rights of the minority in the face of an "interested and overbearing majority." Encouragingly, however, the results suggest that even small minority groups can secure the representation of their views by their legislative representative, even if that member does not identify with the group, through continued visibility and organizing at the district level. The challenge for representative democracy is the translation of localized support for minority rights into broad representation of those rights at the national level in a demographically heterogeneous society.

\section{ACKNOWLEDGMENTS}

We thank Tom Carsey, Christopher Clark, Nicole KalafHughes, Eleanor Neff Powell, Jason Roberts, Menevis Cilizoglu, Bilyana Petrova, Andrew Tyner, and the anonymous reviewers for helpful comments. A previous version of this paper was presented at the 2014 meeting of the Midwest Political Science Association.

\section{REFERENCES}

Adams, James, Benjamin G. Bishin, and Jay K. Dow. 2004. "Representation in Congressional Campaigns: Evidence for Discounting Directional Voting in U.S. Senate Elections." Journal of Politics 66 (2): 80515.

Barth, Jay, L. Marvin Overby, and Scott Huffmon. 2009. "Community Context, Personal Contact, and Support for an Anti-Gay Rights Referendum." Political Research Quarterly 37 (2): 31-50.

Barth, Jay, and Janine Parry. 2009. " $2>1+1$ ? The Impact of Contact with Gay and Lesbian Couples on Attitudes about Gays/Lesbians and Gay-Related Policies.” Politics and Policy 37 (1): 31-50.

Bishin, Benjamin G. 2000. "Constituency Influence in Congress: Does Subconstituency Matter?” Legislative Studies Quarterly 25 (3): 389-415.

Bishin, Benjamin G. 2009. Tyranny of the Minority: The Subconstituency Politics Theory of Representation. Philadelphia: Temple University Press.

Bishin, Benjamin G., and Charles Anthony Smith. 2013. "When Do Legislators Defy Popular Sovereignty? Testing Theories of Minority Representation Using DOMA." Political Research Quarterly 66 (4): 794803.

Bratton, Kathleen A., and Kerry L. Haynie. 1999. "Agenda Setting and Legislative Success in State Legislatures: The Effect of Gender and Race." Journal of Politics 61 (3): 658-79.

Button, James W., Kenneth D. Wald, and Barbara A. Rienzo. 1999. "The Election of Openly Gay Public Officials in American Communities." Urban Affairs Review 35 (2): 188-209.

Campbell, Colton C., and Roger H. Davidson. 2000. "Gay and Lesbian Issues in the Congressional Arena." In Craig A. Rimmerman, Kenneth D. Wald, and Clyde Wilcox, eds., The Politics of Gay Rights. Chicago: University of Chicago Press, 360-62.

Canon, David T. 1999. Race, Redistricting, and Representation: The Unintended Consequences of Black Majority Districts. Chicago: University of Chicago Press.

Clinton, Joshua, Simon Jackman, and Douglas Rivers. 2004. "The Statistical Analysis of Roll Call Data." American Political Science Review 98 (2): 355-70.

Egan, Patrick J. 2012. "Group Cohesion without Group Mobilization.” British Journal of Political Science 42 (3): 597-616.

Fenno, Richard F., Jr. 1978. Home Style: House Members in Their Districts. Glenview, IL: Scott, Foresman.

Gates, Gary J., and Frank Newport. 2013. "LGBT Percentage Highest in D.C., Lowest in North Dakota." Gallup, February 15. http://www.gallup .com/poll/160517/lgbt-percentage-highest-lowest-north-dakota.aspx (accessed September 10, 2013).

Gelman, Andrew, and Thomas C. Little. 1997. "Poststratification into Many Categories Using Hierarchical Logistic Regression.” Survey Methodology 23 (2): 127-35. 
Gentry, Cynthia S. 1987. "Social Distance Regarding Male and Female Homosexuals." Journal of Social Psychology 127 (2): 199-208.

Grose, Christian R. 2011. Congress in Black and White: Race and Representation in Washington and at Home. Cambridge: Cambridge University Press.

Haider-Markel, Donald P. 1999. "Morality Policy and Individual-Level Political Behavior: The Case of Legislative Voting on Lesbian and Gay Issues." Policy Studies Journal 27 (4): 735-49.

Haider-Markel, Donald P. 2010. Out and Running. Washington, DC: Georgetown University Press.

Haider-Markel, Donald P., Mark R. Joslyn, and Chad J. Kniss. 2000. "Minority Group Interests and Political Representation: Gay Elected Officials in the Policy Process." Journal of Politics 62 (2): 568-77.

Haider-Markel, Donald P., and Kenneth J. Meier. 1996. "The Politics of Gay and Lesbian Civil Rights: Expanding the Scope of Conflict." Journal of Politics 58 (2): 332-49.

Haider-Markel, Donald P., and Kenneth J. Meier. 2003. "Legislative Victory, Electoral Uncertainty: Explaining Outcomes in the Battles over Lesbian and Gay Civil Rights." Review of Policy Research 20 (4): 671-90.

Hall, Richard L. 1996. Participation in Congress. New Haven, CT: Yale University Press.

Harden, Jeffrey J. 2013. "Multidimensional Responsiveness: The Determinants of Legislators' Representational Priorities." Legislative Studies Quarterly 38 (2): 155-84.

Herek, Gregory M., and Eric K. Glunt. 1993. "Interpersonal Contact and Heterosexuals' Attitudes toward Gay Men: Results from a National Survey." Journal of Sex Research 30 (3): 239-44.

Herek, Gregory M., Aaron T. Norton, Thomas J. Allen, and Charles L. Sims. 2010. "Demographic, Psychological, and Social Characteristics of Self-Identified Lesbian, Gay, and Bisexual Adults in a U.S. Probability Sample." Sexual Research and Social Policy 7 (3): 176-200.

Herrera, Cheryl Lyn, Richard Herrera, and Eric R. A. N. Smith. 1992. "Public Opinion and Congressional Representation." Public Opinion Quarterly 56 (2): 185-205.

Hertzog, Mark. 1996. The Lavender Vote: Lesbians, Gay Men, and Bisexuals in American Electoral Politics. New York: New York University Press.

Lance, Larry M. 1987. "The Effect of Interaction with Gay Persons on Attitudes toward Homosexuality." Human Relations 6:329-36.

Lax, Jeffrey R., and Justin H. Phillips. 2009a. "Gay Rights in the States Public Opinion and Policy Responsiveness." American Political Science Review 103 (3): 367-86.

Lax, Jeffrey R., and Justin H. Phillips. 2009b. "How Should We Estimate Public Opinion in the States?" American Journal of Political Science 53 (1): $197-21$
Lax, Jeffrey R., and Justin H. Phillips. 2012. "The Democratic Deficit in the States." American Journal of Political Science 56 (1): 148-66.

Lewis, Gregory B., and David W. Pitts. 2009. "Representation of Lesbians and Gay Men in Federal, State, and Local Bureaucracies." Journal of Public Administration Research and Theory 21 (1): 159-80.

Lewis, Gregory B., Marc A. Rogers, and Kenneth Sherrill. 2011. "Lesbian, Gay and Bisexual Voters in the 2000 U.S. Presidential Election." Politics and Policy 39 (5): 655-77.

Lublin, David. 1997. The Paradox of Representation: Racial Gerrymandering and Minority Interests in Congress. Princeton, NJ: Princeton University Press.

Mansbridge, Jane. 1999. "Should Blacks Represent Blacks and Women Represent Women? A Contingent 'Yes'." Journal of Politics 61 (3): 62857.

Mayhew, David. 1974. Congress: The Electoral Connection. New Haven, CT: Yale University Press.

Miler, Kristina C. 2009. "The Limitations of Heuristics for Political Elites." Political Psychology 30 (6): 863-94.

Newport, Frank. 2011. "For First Time, Majority of Americans Favor Legal Gay Marriage.” Gallup, May 20. http://www.gallup.com/poll/147662 /First-Time-Majority-Americans-Favor-Legal-Gay-Marriage.aspx (accessed September 10, 2013).

Overby, L. Marvin, and Jay Barth. 2002. "Contact, Community Context, and Public Attitudes toward Gay Men and Lesbians." Polity 34 (4): 433-56.

Park, David, Andrew Gelman, and Joseph Bafumi. 2004. "Bayesian Multilevel Estimation with Poststratification: State-Level Estimates from National Polls." Political Analysis 12 (4): 375-85.

Pitkin, Hanna. 1967. The Concept of Representation. Berkeley: University of California Press.

Reynolds, Andrew. 2013. "Representation and Rights: The Impact of LGBT Legislators in Comparative Perspective." American Political Science Review 107 (2): 259-74.

Schaffner, Brian, and Nemad Senic. 2006. "Rights or Benefits? Explaining the Sexual Identity Gap in American Political Behavior." Political Research Quarterly 59 (1): 123-32.

Schiller, Wendy J. 1995. "Senators as Political Entrepreneurs: Using Bill Sponsorship to Shape Legislative Agendas." American Journal of Political Science 39:186-203.

Swain, Carol M. 1993. Black Faces, Black Interests: The Representation of African Americans in Congress. Cambridge, MA: Harvard University Press.

Warshaw, Christopher, and Jonathan Rodden. 2012. "How Should We Measure District-Level Opinion on Individual Issues?" Journal of Politics 74 (1): 203-19. 